\title{
EGY KVALITATÍV KUTATÁS EREDMÉNYEI A DÉL-ALFÖLDI RÉGIÓ EGYES MEZŐGAZDASÁGI VÁLLALKOZÁSAINÁL
}

\author{
Vincze-Lendvai Edina ${ }^{1}$, Szücs Kata ${ }^{2}$ \\ ${ }^{1}$ föiskolai docens \\ ${ }^{2}$ Gazdasági és vidékfejlesztési agrámérnök \\ Szegedi Tudományegyetem, Mémöki Kar Ökonómia és Vidékfejlesztési Intézet,
}

\begin{abstract}
SUMMARY
In 2004 Hungary has affiliated to the European Union. The country has been the part of a big economic integration. The (agri)products of the other countries can flow without border. In our work we was wondered the effect of the connection to EU. In our investigation we made seven deep interviews with managers of the Hungarian agricultural, or food enterprises about the changes.
\end{abstract}

Keywords: European Union, South Plain region, enterprises

\section{BEVEZETÉS}

A mezőgazdaság hazánk nemzetgazdaságában tradicionálisan meghatározó szerepet tölt be. Az elmúlt két évtizedben a társadalmi-gazdasági átalakulás, valamint az ágazatok közötti, nemzetközi tendenciáknak megfelelö átrendeződések miatt a magyar agrárgazdaság nemzetgazdaságon belüli súlya, illetve szerepe megváltozott. Az élelmiszeripar ágazatában romló mutatókkal szembesülünk, ami évekre visszavezethető. Néhány országban emelkedett az élelmiszerek iránti kereslet, például Oroszország, Kina, India. A mezőgazdasági termékek árai folyamatosan nőnek, ami annak is köszönhető, hogy alternatív felhasználásként a bioüzemanyagok alapanyagaivá váltak. Emellett az energia árak jelentős mértékü növekedés is folyamatos. Ezen előnytelen tényezők mellet még az időjárás kedvezőtlen voltát is meg tudjuk említeni, ami jelentős károkhoz vezetett, ilyen pl. az árvíz, a belvíz, a tavaszi fagy, valamint az aszály (www.agrarhirek.hu).

\section{SZAKIRODALMI ȦTTEKINTÉS}

Az Unióban fontos alapelv, hogy minél magasabb feldolgozottságú termékeket állítsanak elő, és ezek eljussanak a magyar lakossághoz (is). Választanunk kell: alapanyag-termelö, kevés jövedelmet, profitot termelő ország kívánunk lenni, vagy inkább magasabb hozzáadott értékkel rendelkezö termékeket kívánunk elöállítani.

Hazánk élelmiszeriparának a várható fejlödését több tényező is befolyásolni fogja, melyek közül az alábbiak a legfontosabbak:

- a mezőgazdasági termékek árainak alakulása

- foglalkoztatottak béreinek alakulása

- multinacionális üzletláncok árpolitikájának tendenciája.

- az adópolitika változása

- banki kamatterhek változása (Popp - Potori - Udovecz, 2009).

A piaci versenyképességünket akadályozó tényezök között szerepel mezőgazdaság és a feldolgozóipar átalakulása, illetve következménye, a vertikális integráció megszủnése. A vállalkozók hozzáállása sem megfelelö, azonnali pénznyerésre számítanak, és nem fordítanak figyelmet a jövőre. Hazánkban -mint más országban is - jellemzően csak kis- és közepes méretủ vállalkozások vannak, melyek alacsony gyártókapacitással rendelkeznek és ebböl adódóan a feldolgozási költségük igen magas. 
A szürke- és fekete-gazdaságnak a szerepe az élelmiszergazdaságban igen jelentős, szinte eléri a 25-30\%-ot. Megoldásként sokan az ÁFA-csökkentést javasolják. Kiemelhetjük még a multinacionális cégek szerepét, amelyek a beszállitókkal nem túl etikus magatartást folytatnak - elsősorban a fizetések terén (Avar, 2011 www.trademagazin.hu).

\section{ANYAG ÉS MÓDSZER}

A kutatás során néhány Dél-Alföldön müködő, mezőgazdasági termények feldolgozásával foglalkozó vállalkozást kerestünk fel.

A megkérdezett vezetök az alábbi cégeket képviselték:

- Univer Product Zrt. - Kecskemét

- Royal Sütöde Kft. - Jánoshalma

- Rubin Szegedi Paprikafeldolgozó Kft.

- Elma Zrt ${ }^{2}$. - Érsekhalma

- Bács-Zöldért Zrt.

- Felsöbácskai Mümalom

- Szabó-Kern Sütőipari Kft.

A vezetökkel készített strukturált interjúk során az alábbi föbb témák kerültek szóba:

- A vállalkozás jelenlegi és korábbi termékei

- Tevékenységi körök

- Fontosabb célcsoportok a csatlakozás elött és után

- Kapcsolatban álló cégek

- Pályázatok és elnyerésük

- Az EU csatlakozás okozta változások

- Jövöbeni tervek

Az interjúk feldolgozása alapján nyert információk összegzésre kerültek, valamint egy, az Agrárgazdasági Kutató Intézet által végzett felméréssel vetettük össze a kapott eredményeket.

\section{EREDMÉNYEK ÉS ÉRTÉKELÉSÜK}

Az alábbiakban a vezetők által elmondottak kerülnek feldolgozásra.

A meginterjúvolt cégek túlnyomó többségében a kezdeti termékeiket megörizték, amelyeket müködésük kezdetén is gyártottak. Ez minden cég esetében pár terméket jelentett csupán. A mai kínálatot tekintve azonban jelentős bövülést lehet megfigyelni minden egyes cég esetében. A vállalatvezetök elmondták, hogy a kínálat bővitése szükséges volt, mert a vásárlói igények elörehaladtával, illetve bővülésével a fogyasztó kör keresletét ki kell elégíteniük a vállalatoknak. A malom ez alól kivételt képez, mert ott mára csak a búza maradt meg, mint fö termék. A termékek készitése esetében igen szerteágazó a megkérdezett cégek palettája. Ezek a termékek az alábbiak: alma süritmény, különbözö fajtájú lisztek, füszerpaprika örlemény, paradicsom sürítmény, kovászos uborka, piros arany, paprika krém, majonézes torma, kenyér, zsemle félék. Azonban vannak olyan vállaltok is, amelyek nem dolgozzák fel termékeiket, hanem csak csomagolják, hütik és tovább szállítják.

A minöség fontos szerepet tölt be az interjúalanyaim körében. A gyártmányok körében különbözö minőségi osztályok vannak, melyek befolyásolják az árak alakulását. A termék minöségi kategóriája alapján kerül besorolás alá. Vannak olyanok is, mint pl. a sütö üzemek, ahol, ha a termék minősége nem megfelelö, akkor nem kerülhet kereskedelmi forgalomba. Az

\footnotetext{
${ }^{2}$ A vállalat ellen - a kutatás elvégzése óta - a megváltozott gazdasági helyzet miatt felszámolási eljárás indulhat
} 
Univer esetében nincsenek minőségi kategóriák, mert már a beszerzésnél csak egy minőségi kategória van, és annak kell megfelelnie a terméknek.

A célcsoport tekintetében azt lehet mondani, hogy a cégek túlnyomó része próbál minden fogyasztói réteg számára megfelelni a termékeivel. A malmok esetében még a pékek, sütöüzemek is komoly célcsoportnak számítanak.

A tevékenységi kör minden megkérdezett vállalkozás esetében más és más. A gyümölcslégyártás esetében gyümölcstermesztés, -feldolgozás, és -légyártás. Malom esetében a fö tevékenységek a tárolás, őrlés, csomagolás. Füszerpaprika gyártása esetén őrlés és csomagolás. Az Univer több tevékenységet is felsorolt, megemlítésre került a termelés, a logisztika, az értékesités.

A foglalkoztatottságot vizsgálva megállapitható, hogy vannak olyan vállalatok, akik sok embernek tudnak munkát biztositani, de vannak olyanok is, akik csak pár fövel müködnek. ( $\mathrm{Pl}$. Univer, 540 fö. Elma, kb. 100 fö.) Igen alacsony létszámmal folytatja müködését a malom, a kedvezötlen gazdasági események miatt kénytelenek voltak megválni dolgozóiktól. A Royal sütőüzemben is alacsony a dolgozói létszám, de ez csak a jánoshalmi kirendeltség, és más városban is vannak még dolgozói.

A megkérdezett vállaltok esetében a kapcsolati listán szerepelnek beszállító cégek, magán vállalkozások, multinacionális cégek, nagykereskedők, valamint a legfontosabbak a hivatalos szervek, mint például a Mezőgazdasági Szakigazgatási Hivatal, az ẢNTSZ, a tűzoltóság, és különböző kutató cégek. A mélyinterjú alanyaim túlnyomó része jól kiépített külföldi kapcsolatrendszerrel rendelkezik, állandó export piacaik vannak más országokkal. A kivételek azzal magyarázták az export hiányát, hogy régebben volt, de mára annyira leépültek, hogy már nem éri meg a számukra, valamint a sütöüzemeknek egyáltalán nem is volt és nem is lesz. Ez az az iparág, amelynek nem lenne szerencsés a termékeik kivitele. Az export területek közül a legmeghatározóbb Németország és Ausztria, de ezen kívül még Hollandia, Románia, Horvátország, Lengyelország, Ausztrália és Szlovákia is szóba került.

A belföldi kapcsolatok sorában a megkérdezettek többsége az egész ország területén rendelkezik összeköttetéssel, illetve meg lehet találni öket országszerte. A belföldi kapcsolatok közül leginkább a nagyobb multi cégeket lehet megemlíteni e tekintetében, mint a Tesco, a Lidl, de a kapcsolatok között szerepelnek általános iskolák is, akikkel különböző programok keretében alakulnak ki ismeretségek. Egyes vállalatok kimondottan a déli régióra koncentrálnak, és nem terjeszkednek más irányban. Számukra ez a régió az, ahol már a bevált, megszokott kapcsolat- rendszerük megtalálható, illetve kiépített.

Áttérve egy másik témára a pályázati lehetőségekröl beszélgettünk. Az elmúlt években az uniós pályázatok nagy teret hódítottak maguknak. Sokan éltek ezzel a lehetőséggel, és az interjúalanyaim között is volt olyan, akik sikeres pályázatokkal rendelkeznek. Különböző területekre pályáztak. A megvalósult pályázatok között szerepelt sủritmény-tároló építés, lékonyha-modernizálás, bekötőút felújitás, termékek értéknövelése, informatikai fejlesztések, paprikanemesítés, gépvásárlás. Voltak olyanok is, akik pályáztak, azonban nem volt sikeres a pályázatuk, de optimisták és pályáznak továbbra is.

Az Európai Unióhoz való csatlakozásról a vélemények megoszlottak a válaszadóim körében. Vannak, akikre kedvező hatással volt, olyan lehetőségeket emlatettek, mint az áru gyorsabb célba érése, az export és import kedvezőbb hatása, kevesebb dokumentációs munka, valamint a piaci résztvevők számának az emelkedése. Emellett azonban a kedvezőtlennek vélt csatlakozási hatást is hangoztatták, mely megnyilvánul a vámok ügyintézésében, a lecsökkent termelésben, kisebb vásárló- erőben, piaci részarány csökkenésében, gyártó magas szintü ellenőrzésében. Végezetül a jövőre vonatkozó tervek kerültek szóba. Elmondható, hogy mindenki optimistán tekint a jövőbe és jól kidolgozott tervekkel rendelkezik, melyek közéaz alábbiak tartoznak: új termékek bevezetése, épületek felújítása, építése, mélyhütés kialakítás, szárítás lehetővé tétele, csomagolások újítása, reformálása, és a vevők igényeinek a megfelelő 
szintü kielégítése. Egyetlen vállalat pesszimistábban vélekedett, ők nem rendelkeznek a jövőre nézve tervekkel, mivel a nagy multinacionális vállalatok az olcsóbb termékeikkel kiszorítják öket a piacról.

\section{5. ÖSSZEFOGLALÁS}

Az Agrárgazdasági Kutató Intézet (AKI) 2009-ben elkészített egy tanulmányt, melyben 9 élelmiszeripari szakágazattal foglalkoznak (Bojtár et al., 2009). Vizsgálták a pénzügyi helyzeteiket, a vállalkozás-fejlesztési stratégiájukat, a lezajlott legfontosabb változásokat és azok hatásait - pl. az emberi erőforrás, a tőkeellátottság, a hatékonyság szempontjából.

A stratégiai típusok alapján az AKI négy jelleget különböztet meg, melyek az alábbiak:

1. Felélő típus

2. Túlélő típus

3. Optimalizáló típus

4. Buldózer típus

Ebbe a négy típusba soroltuk be az általunk vizsgált vállalatokat..

$\mathrm{Az}$ első típusba került a Felsőbácskai Mümalom - nehéz pénzügyi helyzetben vannak, árbevételük folyamatosan csökken, valamint csökkent a foglalkoztatottak létszáma és fokozatos a vagyonvesztésük. Mára már azt fontolgatják, hogy eladják a malmot.

A második típusúak közé egyik vállalat sem tartozik a kutatásban résztvevők közül.

Az optimalizáló típus a harmadik, melybe a Royal Sütöde Kft-t és a Bács-Zöldért Zrt-t sorolhatjuk. Mind a két vállalatot bizonyos szinten átszervezték, csökkent a foglalkoztatottjainak a létszáma, bizonyos tevékenységek megszüntek, azonban jelentősebb beruházás nélkül is optimálisabban tudnak müködni, javult a jövedelmezőségük és a hatékonyságuk. A képzettebb foglalkoztatottak megmaradtak.

A negyedik kategóriába egyik vállalat sem került.

A fenti kategóriákba be nem sorolhatók cégekröl az alábbiak mondhatók el:

- Az Univer Product Zrt., jelentős növekedést tudott produkálni, mind az eszközök, mind a foglalkoztatottság terén, nincs jelentős hitelállományuk és nincsenek eladósodva.

- A Rubin Szegedi Paprikafeldolgozó Kft., fejlődésnek induló vállalat, mind a terjeszkedést tekintve, mind pedig a foglalkoztatás és az árbevétel szempontjából.

A vállalatok elött tehát kihívások és további lehetőségek állnak, de a külső környezet jelentős hatással van arra, hogy mennyiben tudják ezeket megvalósítani.

\section{IRODALOMJEGYZÉK}

Avar László (2011): ÁFA-csökkentés a feketegazdaság ellen. Magyar Mezőgazdaság. 66. évf. 17. szám, 19. o.

Bojtárné Lukácsik Mónika, Felkai Beáta Olga, Györe Dániel, Kapronczai István, Kürti Andrea, Székelyné Raál Éva, Tóth Pirosak, Vágó Szabolcs (2009): Tulajdonosi és szervezeti változások a hazai élelmiszeriparban. Agrárgazdasági Kutatóintézet, Budapest

Popp József - Potori Norbert - Udovecz Gábor (2009): A versenyesélyek javításának lehetőségei a magyar élelmiszergazdaságban, Agrárgazdasági Kutató Intézet, Budapest

http://www.agrarhirek.hu/innovacio/477.html

http://www.trademagazin.hu/piaci-hirek/merre-tovabb-hazai-elelmiszeripar-avagy-van-e-szuksegmagyarorszagon-iparszeru-elelmiszer-eloallitasra.html\#.TolcBMNZyoQ.email 